\title{
P. OXY. XXXV 2737 and Alcman's Ancient Reception
}

\section{Vasiliki Kousoulini}

\begin{abstract}
Despite the fact that P. Oxy. XXXV 2737 has been the subject of scholarly debate, its significance for the study of Alcman's ancient reception has been left unnoticed. P. Oxy. XXXV 2737 provides indications that Alcman's name was, possibly, involved in the poetic rivalry between Aristophanes and his fellow-comedians, and that Aristophanes and his audience were both aware of Alcman's compositions.
\end{abstract}

\section{Keywords}

Alcman; ancient reception; papyri 
Although P. Oxy. XXXV 2737 has been widely discussed by modern scholarship, ${ }^{1}$ the fact that it may also be used as a source of information regarding Alcman's ancient reception has been overlooked. More specifically, I suggest that P. Oxy. XXXV 2737 provides indications that Alcman's poetry, or at least some excerpts of it, was known in Athens during the classical era. ${ }^{2}$

P. Oxy. XXXV 2737, fr. 1, col. II, 18-19

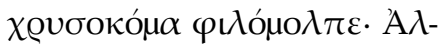

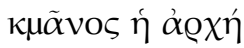

"Golden-haired song-lover:

the beginning (of Aristophanes) belongs to Alcman."3

P. Oxy. XXXV was produced during the late second century A. D., but it preserves information regarding earlier literature and scholarship. More specifically, it comes from a commentary on a play of Aristophanes. ${ }^{4}$ It was first edited and published by Lobel. ${ }^{5}$ It preserves information regarding Alcman's ancient reception in its first and second columns. According to P. Oxy. XXXV 2737, ancient scholars believed that the parabasis of one of Aristophanes' plays was heavily influenced by Alcman. The editor of the pa-

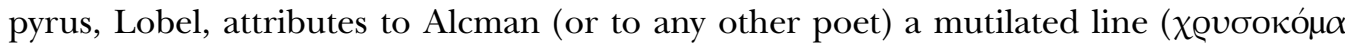
$\varphi(\lambda o ́ \mu o \lambda \pi \varepsilon)$. Lobel believes that this line belongs to a hymn to Apollo composed in the style of the Homeric hymns. ${ }^{6}$ Lobel thinks that it comes from the beginning of the first poem of the first book of Alcman's Alexandrian edition. ${ }^{7}$ If this is true, then it should be

1 P. Oxy. XXXV 2737 has, usually, been used as a source of information regarding Aristophanes, the career of the comic poet Plato, and the rules of the production of comedy. See on this Sutton (1976: pp. 125-127); Mastromarco (1978: pp. 19-34); Sutton (1980: pp. 59-63); Luppe (1982: pp. 147-159); Mastromarco (1983: pp. 29-35); Luppe (1984: pp. 15-16); Rosen (1989: pp. 223-228); Gilula (1990: pp. 101-102). Gelzer's study has a different approach (see Gelzer 1972: pp. 141-152).

2 Hinge in his meticulous study of Alcman's language briefly refers to the issue of Alcman's ancient reception. According to Hinge, Alcman's poetry was relatively unknown until the Hellenistic times and only a small collection of Alcman's non-ritual songs were known outside Sparta during the classical times. See on this Hinge (2006: pp. 2-3); Hinge (2009). Carey believes that Alcman had a Panhellenic reception, even during the classical times (see Carey 2011: pp. 437-461).

3 The translation belongs to Campbell (see Campbell 1988: p. 403).

4 Modern scholars tend to identify this play with Anagyros. See on this Luppe (1971: pp. 101-102); Gelzer (1972: p. 141); Luppe (1973: pp. 275-288).

5 See Lobel (1968). It is not certain whether or not this hypomnema was influenced by the Didymean exegesis (see on this issue McNamee 1977: p. 189; Bastianini 2006: p. 161, n. 22). It was probably shortened (see Bastianini 2006: p. 170).

6 See Lobel (1968). Lobel thinks that it comes from the beginning of the first poem of the first book of Alcman's edition (thus from a partheneion). It is very likely that this phrase was used by the poet to invoke Apollo. See on this Gelzer (1972: p. 142); Calame (1983: p. 305); Davies (1991: p. 24).

7 In the papyrus we can indeed read: $A \lambda \kappa \mu \tilde{\alpha} v o \varsigma \dot{\eta} \dot{\alpha} \varrho \chi \eta \dot{~(l i n e ~ 19), ~ b u t ~ t h i s ~ i s ~ n o t ~ s o l i d ~ p r o o f . ~ I t ~ i s ~ f a r ~ f r o m ~}$ certain that this is the first line of Alcman's poems according to the Alexandrian edition (thus that it belongs to a partheneion). It can also be the beginning of a comedy of Aristophanes who borrowed a line that belonged to Alcman. Page (see Page 1971: p. 97) believes that is not impossible that this line belonged to the first strophe of a choral part of an aristophanic comedy. 
supposed that this line came from a partheneion. ${ }^{8}$ Other contemporary scholars believe that this commentary contained a polemic against Eupolis, who used to "borrow" fragments from other poets, according to the ancient tradition. ${ }^{9}$ Could Aristophanes, in the parabasis of Anagyros, mention these lines as an example of Eupolis' tactic of quoting lyric poetry? Or could Aristophanes have used a few lines of Alcman's poetry in order to mimic Eupolis, using Eupolis' favorite literary device? Whatever the case was, it is important that Alcman's songs, and most probably Alcman's cultic songs, seem to have been a source of inspiration for Attic comedy.

P. Oxy. XXXV 2737, fr. 1, col. I, 19-28

$[\kappa u ́-$

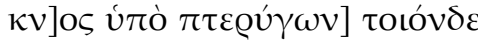

]

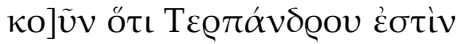

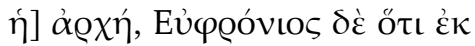

$\tau \tilde{\omega} v^{\prime \prime} \mathrm{I}[\omega] \operatorname{vos} \mu \varepsilon \lambda \tilde{\omega} v$, ó $\delta \dot{\varepsilon} \tau \dot{\eta} v$

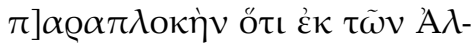

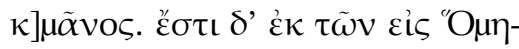

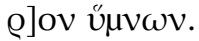

"The swan to the accompaniment of his wings (sings a song) such as this: the view of Aristarchus is that the beginning (of Aristophanic stanza) is by Terpander, Euphronius thinks it is from Ion's songs, the author of Paraploke thinks it comes from Alcman's songs; but it comes from hymns ascribed to Homer." 10

In the first column of the same papyrus we encounter a fragment which is attributed

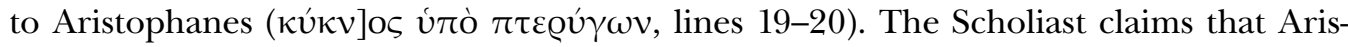
tophanes' fragment belonged to a line that was composed in the style of the Homeric hymns (line 26) or that it comes from one of the Homeric hymns, ${ }^{11}$ and he claims that it has been attributed by other ancient scholars to different poets (lines 21-24). ${ }^{12}$

8 See Calame (1983: p. 305). Page believes that the ancient scholiast attested that this was the first line of Aristophanes who had borrowed it from Alcman (see Page 1971: p. 97). Even if it was not an excerpt of a partheneion, this line was certainly an excerpt of a hymn or of another cultic song.

9 See Hofmann (1970: p. 10). This is not the first time that Eupolis' name is connected with Alcman's in the ancient tradition. Athenaeus (14.638e) quotes a fragment of Eupolis's Helots. The speaker was, probably, the chorus of helots and it referred to the habit of the Athenian symposiasts to recite verses of lyric poetry accompanied by the lyre. Eupolis' fragment is the only testimony regarding the re-performance of Alcman's songs during the classical era.

10 The translation belongs to Campbell (see Campbell 1988: pp. 404-405).

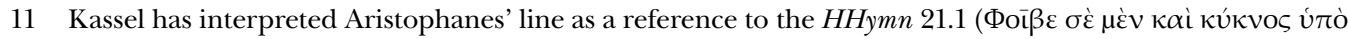

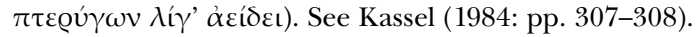

12 Aristarchus attributed it to Terpander, Euphronius attributed it to Ion of Chios, and a third anonymous source attributed it to Alcman. Euphronius was a Hellenistic scholar who lived around the time of Aristophanes of Byzantium. He was the author of commentaries of individual plays by the comic poet Aristophanes and he was interested in the literary use of proverbs (see on this Montana 2015: pp. 126-127). His name is never mentioned in the Alcmanic scholia. On the contrary, Aristarchus' name is often encountered in Alcmanic papyri (on a recent edition of the papyri of Alcman see Römer 2013). 


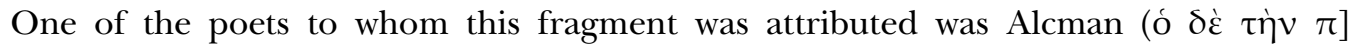

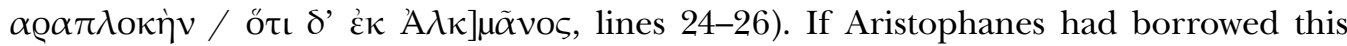
line from one of Alcman's compositions, it is not impossible to regard that this line might have belonged to 1 PMGF, since in its last lines (101 and on) the poet refers to a swan and the papyrus is heavily mutilated. This is a mere speculation, but in case it contains segments of truth, we can suppose that an ancient scholar believed that fragment $1 P M G F$ was a hymn and that he did not use the term partheneion to describe it. The scholarly dispute over its authorship attests that this phrase was used by all these poets. ${ }^{13}$ It is also logical that it was, probably, first used in the Homeric Hymn 21 to Apollo. Hymn 21 is a short prooimion to a larger work. Beecroft suggested that this gives us a clue about the function of this phrase. It is possible that this phrase was formulaic or of proverbial origin and was attributed to different authors by ancient scholars, depending on which dating scheme and which theory of the origin of the prooimion a given ancient scholar preferred. ${ }^{14}$

According to the indications that P. Oxy. XXXV 2737 brings to light, Alcman's name was, possibly, involved in the poetic rivalry between Aristophanes and his fellow-comedians. It is also possible that Alcman's name was involved in the scholarly debate regarding the origin of the prooimion as a genre. What is more important is that Aristophanes and his rivals seem to be aware of Alcman's songs and to quote them in their poetic compositions, as if Alcman was a well-known poet in classical Athens. P. Oxy. XXXV 2737 does not answer all the questions regarding Alcman's ancient reception. Nevertheless, the information provided by this papyrus implies that Alcman's songs were known in classical Athens by the comic poets and their audience.

\section{Bibliography}

Bastianini, G., Haslam, M., Maehler, H., Montanari, F., \& Römer, C. E. (2006). Commentaria et Lexica Graeca in Papyris reperta (CLGP; Vol. 1, Fasc. 4, Aristophanes - Bacchylides). München Leipzig: De Gruyter.

Beecroft, A. (2008). Nine Fragments in Search of an Author: Poetic Links Attributed to Terpander. The Classical Journal, 103(3), 225-241.

Bowra, C. M. (1961). Greek Lyric Poetry from Alcman to Simonides. Oxford: Clarendon Press.

Calame, C. (1983). Alcman. Texte critique, témoignages, traduction et commentaire. Roma: Edizioni dell'Ateneo.

13 See on this Calame (1983: p. 618).

14 See Beecroft (2008: p. 229). Bowra was the first to suggest that some of Alcman's hexametrical fragments were similar to the prooimia attributed to Terpander (see Bowra 1961: pp. 22-25). Power also thought that some of Alcman's fragments (26, 38, 39, 107 PMGF), hexametrical or not, may come from prooimia sung solely by the cithara player or were parts of abbreviated proemial invocations (14, 27, 29 PMGF) sung by the chorus to mark the start of their own singing (see on this Power 2010: p. 202). Kousoulini (see Kousoulini 2013: pp. 420-440) explores the possibility that Alcman's hexametrical fragments were preludes to partheneia. 
Campbell, D. A. (1988). Greek Lyric Poetry, Vol. II: Anacreon, Anacreontea, Choral Lyric from Olympus to Alcman. Cambridge, MA: Harvard University Press.

Carey, C. (2011). Alcman from Laconia to Alexandria. In L. Athanassaki, \& E. Bowie (Eds.), Archaic and Classical Choral Song: Performance, Politics and Dissemination (pp. 437-460). Berlin: De Gruyter.

Davies, M. (1991). Poetarum Melicorum Graecorum Fragmenta. Alcman, Stesichorus, Ibycus. Oxford: Oxford University Press.

Gelzer, T. (1972). Alte Komödie und hohe Lyrik. Bemerkungen zu den Oden in Pap. Oxy. 2737. Museum Helveticum, 29, 141-152.

Gilula, D. (1990). P. Oxy. 2737 and Aristophanes' Early Career. Zeitschrift für Papyrologie und Epigraphik, 81, 101-102.

Hinge, G. (2006). Die Sprache Alkmans: Textgeschichte und Sprachgeschichte. Wiesbaden: Reichert.

Hinge, G. (2009). Cultic Persona and the Transmission of the Partheneions. [Retrieved 09.04.2017 from http://alkman.glossa.dk/chorus.html].

Hofmann, H. (1970). Ein Kommentar zum "Anagyros" des Aristophanes (P. Oxy. 2737). Zeitschrift für Papyrologie und Epigraphik, 5, 1-10.

Kassel, R. (1984). Aristophanes. Testimonia et Fragmenta. Berlin: De Gruyter.

Kousoulini, V. (2013). Alcmanic Hexameters and Early Hexametric Poetry: Alcman's Poetry in its Oral Context. Greek, Roman and Byzantine Studies, 53(3), 420-440.

Lobel, E. (1968). The Oxyrhynchus Papyri (Vol. XXXV). London: Egypt Exploration Society.

Luppe, W. (1971). Der "Anagyros" - Kommentar Pap. Oxy. 2737. Archiv für Papyrusforschung und verwandte Gebiete, 21, 93-110.

Luppe, W. (1973). “Anagyros” - oder nicht? Zur Identifizierung von Pap. Oxy. 2737. Zeitschrift für Papyrologie und Epigraphik, 11, 275-288.

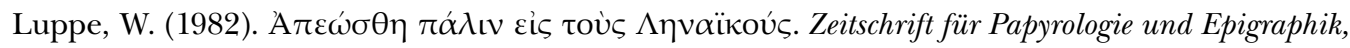
$46,147-159$.

Luppe, W. (1984). Der Komiker Platon und die Dionysien. Zeitschrift für Papyrologie und Epigraphik, 54, 15-16.

Mastromarco, G. (1978). Una norma agonistica del teatro di Atene. Rheinisches Museum, 121, 19-34.

Mastromarco, G. (1983). Gli esordi di Aristofane e di Platone comico. Zeitschrift für Papyrologie und Epigraphik, 51, 29-35.

McNamee, K. (1977). Marginalia and Commentaries in Greek Literary Papyri (Diss. Duke University). Ann Arbor, Michigan: University Microfilms International.

Montana, F. (2015). Hellenistic Scholarship. In F. Montana, S. Matthaios, \& A. Rengakos (Eds.), Brill's Companion to Ancient Greek Scholarship (Vol. 1; pp. 60-183). Leiden - Boston: Brill.

Page, D. L. (1971). Ibycus, Stesichorus, Alcman, P. Oxy. 2735, 2618, 2737. Proceedings of the Cambridge Philological Society, 197, 89-98.

Power, T. (2010). The Culture of Kitharoidia. Cambridge, MA - London: Harvard University Press.

Römer, C. (2013). Commentaria et Lexica Graeca in Papyris reperta (Vol. 2, Fasc. 1, Alcman). Berlin: De Gruyter.

Rosen, R. M. (1989). Trouble in the Early Career of Plato Comicus: Another Look at P. Oxy. 2737. Zeitschrift für Papyrologie und Epigraphik, 76, 223-228.

Sutton, D. (1976). P. Oxy. XXXV 2737: New Light on the Production of Old Comedy. The Bulletin of the American Society of Papyrologists, 13, 125-127. 
Sutton, D. (1980). Plato Comicus Demoted: A Reconsideration. Zeitschrift für Papyrologie und Epigraphik, 38, 59-63.

Dr. Vasiliki Kousoulini, PhD. / vasiakous@yahoo.gr School of Philosophy, Department of Philology, Sector of Classics National and Kapodistrian University of Athens Panepistimiopolis 15784, Ilissia, Greece 